\title{
The Perspective of Kuwaiti Students Towards the Effectiveness and Value of Self-Study
}

\author{
Ali A. Taqi ${ }^{1}$ \\ ${ }^{1}$ The Foundation and Administration of Education Department, College of Basic education, Ardhyia, Kuwait \\ Correspondence: Ali A. Taqi, The Foundation and Administration of Education Department, College of Basic \\ education, Ardhyia, Kuwait.
}

Received: April 15, 2019

doi:10.5539/ies.v12n9p105
Accepted: June 1, 2019 Online Published: August 29, 2019

URL: https://doi.org/10.5539/ies.v12n9p105

\begin{abstract}
Through self-study, students are believed to develop new learning strategies, new motivation, reflection and critical thinking. The current study was conducted in the College of Basic Education, the English Department Kuwait. 324 female students participated in answering an extensive questionnaire related to the topic of self-study. In addition, group interviews were conducted by the researcher, which assisted in gaining further in sight of the students' point of view related to the importance of self-study and reasons behind their selection. While most participating students recommended self-learning, they also insisted on the importance of the teacher's role. This study is believed to assist curriculum developers, educational administration and teachers in developing appropriate curriculum and syllabus that suits the needs of a new generation.
\end{abstract}

Keywords: motivation, self-study, EFL, ESL, curriculum, education

\section{Introduction}

Self-learning is a method with which students acknowledge the learning requirements, goals and learning sources independently, with or without assistance (Knowles, 1975; Simica \& Trastaru, 2013). Self-learning is believed to be a valuable art skillfully self-discipline embedded in educational and working fields (Oliver \& Simone, 2006). In the field of education, a student's attempts to acquire information by a self-established process are regarded suitable by the student. Self-learning could only be established once the student is aware of its necessity and feels the responsibility to learn.

The main aim of issuing a self-study is engaging students and mental process whereby data is searched for and investigated by the use of any facilities available. In this process, students assume responsibility and guide themselves into their individually designed learning strategy (Long, 2006). The comparison is in between self-coordinated learning and teacher-instructed learning has been always under investigation (White, 2006). Moreover, the introduction of self-study in higher education has not always proven to be effective (Levett-Jones, 2005). Yet, most teachers and educators search for the skills and equipment required being a successful self-guided learner. Hence, the questions posed were; what are the social and educational settings required? Are there cultural skills needed by the self-guided learning? Are there personal traits and past experiences that affect self-study? Researchers believe that the answer to these questions is all positive, and all these skills and experiences are required to enhance the ability to start a self-study process (Greveson \& Spencer, 2005). Most educators agree that self-directed learning could be achieved within certain personal skills and traits such as the ability to manage time, set goals, process information, be decisive and have confidence in decision making (Long, 2006).

The concept of autonomy in language learning started in the late 1960s, it initially started by an adult learners in Europe and North America; autonomous learning was associated with adult learners, who no longer pursue formal education for many years (Benson, 2004). After many years of associating autonomous learning with learning at home, Holec published a book in 1981 called Autonomy and Foreign Language Learning, setting a change point in the view of autonomous learning of language. From then on, autonomy of language learning meant any study of language, official or not, where the learner becomes in charge or his/her own learning.

Most educators would agree that language classrooms consist of a heterogeneous blend of students who have different degrees of social, cultural and educational skills. Additionally, while the techniques of language learning would differ between the learners according to the skills they possess, this current research aims at finding whether 
every EFL student could gain, in a certain degree, from the experience of self-learning. This paper will start with a review of current literature in the field of self-study. This would be followed by the research questions and the methodology by which these questions could be answered. A discussion of the findings that would assist in reaching definite conclusions and offer recommendations that would be useful to educators and students alike would be offered at the end.

\section{Literature Review}

The requirements of the educational process have changed with the changes that occurred in the realm of education. With the occurrence of new technologies and globalization, the traditional method of instruction seems to have lost its appeal to a more self-directed, self-guided method that would enhance communication, social and intellectual skills. The learners, according to Rupšiene and Bartusevičienè (2011), have moved from the traditional paradigm of instruction towards a more constructive approach, which relies mainly on independent learning.

While there is no agreed-upon definition of self-study, most definitions use the word "independent" and/or "autonomy" to define self-study. For example, the Cambridge English dictionary defines self-study as a method of learning a topic by studying "alone at home" rather than in a traditional classroom setting. Moore (1973), on the other hand, defined self-study as the capability and motivation of autonomous learners to control their learning environments, through several learning processes. Baird (1988) also believed that independent learners should be responsible for their own autonomous learning, through planning, managing and assessing their own learning which in turn guarantees higher efficiency. Rajeckas (1999) noted that teachers should create the perfect environment of independent study by emphasizing the importance of self-study so as not to confuse students to think that this method of learning is always optional. This in turn would help students shift their personal learners' autonomy to include self-study skills.

Certain characteristics form autonomous learning. Jovaiša (2007) states that motivation is part of independence. Thus, a teacher's role in self-study assignments is to motivate students to solve research problems by looking for different approaches that may be used separately or combined according to the learning required. This idea follows on Dickinson's (1993) three traits of autonomous education. The first trait is the ability of students to work in their own pace; secondly, students will have the freedom to make related choices that would suit their own learning needs; and thirdly, participating independently and actively in the learning process. Dickinson (1993) added that through autonomous learning, students would reach the same learning goal by choosing their self-designed approach and the timing that suits them best; this would enhance self-awareness and reflecting on one's work which in turn would make better learners (Benson \& Volter, 1997).

Traditionally, learner autonomy has been linked with learning outside the classroom; the usefulness of self-study in schools has been introduced lately as a student-centered approach. As a matter of fact, the previous mentioned aspects of learner autonomy fits language learning very well. Yet, it is essential to start with the change of the roles and relationships in the language classroom. Since learner autonomy is about the students' control over their own learning, hence, the teacher needs to change his/her roles from someone an authority responsible for the students' learning to a facilitator and a guide in the learning process that is controlled by the learners (Voller 1997, p. 101). Secondly, since the role of the teacher has changes, so does the role of the students; dependence on and need for teaching and controlling that the EFL learners have been conditioned to by previous experiences on language learning need to be "deconditioned" (Holec, 1981, p. 30). In other words, the learners need to become active in the learning process instead of being passive recipients of taught information. Once both the teacher and the learners have understood and accepted their new roles and 19 relationships in the learning process, learner autonomy can take place in the language classroom. Several skills have been identified as necessary for independent learners. Developing the autonomy of the learner is an important factor to consider. According to Ebata (2010) teachers, suitable content, a cooperative environment which is mainly student-centered, and teaching useful skills are the most essential. Motivation as Ebata (2010) stated would reach its highest level due to emphasis on these factors. Johnson \& Johnson (1999) identified three main skills needed to self- study: self-management skills, critical thinking and creative thinking. Self- management would include time management and the material chosen; while critical thinking allows the understanding of the material rather than mere memorizing; and creative thinking allows finding solutions to problems and thinking out of the box. With more practice, these self-study skills will develop and become part of the student's learning process and learning habits. Jatkauskiené and Le Boterf (2012) agrees that the purpose of independent learning is emphasizing self-study traits such as developing a systematic autonomous approach of study independently, organizing time and material, developing imagination and hence creativity, and identifying categories and actions required for the different learning approaches. Thus, learners will be able to accumulate the information required and critically analyze it making it more valuable and meaningful than the mere knowledge of facts (Herring, 1998; Vikonis \& Barabanova, 2010). 
In order to advocate for self-study, teachers must be prepared to guide students through the process until they have acquired the skills needed to be independent learners. The students will become better at self-study, for example, if they were provided sufficient course information such as the aim of the taken course (Ciburiené \& Guščinskiené, 2012). Teachers are required to involve students in authentic projects, emphasizing the need for tolerance, attention, expertise in the field and experience (Pukelis \& Savickiene, 2011). Enable to set higher education students on a self-study experience, Daukilas (2010) believes that the teacher should design a suitable educational paradigm including democracy as an important teaching style, use of the latest technology (especially the internet based technology) to guaranty interactivity of learning, teacher's should introduce a variety of methods that could be utilized in the teaching/learning process, and reinforce social physical and emotional skills. Although limited, but a teacher's role in self-study activities is essential as it guides students through the process to avoid blind memorization from textbooks and instead search for logical explanations that enables them to solve problematic questions. Teachers are expected to introduce certain topics that would encourage self-study, providing them with explanations of the autonomy of their learning and the execution process in context. Once the student starts, teacher could provide feedback which allows the improvement of the student's work. Teachers should, however, emphasize that self-study does not mean being cut off from the world; rather it is a social and interactive method that requires social contact with peers and teachers to be able to prepare the projects adequately.

Currently, the teacher's goal, when teaching a foreign language, aims at developing the learners' communicative abilities in the target language. In order to make the most of autonomous learning, the teacher should engage her /his students in the activities as much as possible, providing them with authentic communication that is interesting and relevant to the learners. This may include the use of common words or phrases in the second language to give the students a sense of authenticity. In previous studies on the study of English as a foreign language, it has been shown that teenage German and Sweden students already knew many English words before their first English lesson (Whartorn, 2000; Palmberg, 1985, respectively); and with the availability of the internet, this has become true of students of younger ages. When it comes to self-study in language learning, Nunan (2000) set a concise concept of autonomy in language learning linking it directly to the communicative approach. According to this approach, if the second/foreign language learners are allowed to design their own study approach, the learner would learn the language effectively. Nunan (2000) designed an organized, step by step analysis of the development of the learner's independence. Table 1 reflects Nunan's (2000) analysis.

Table 1. Steps to develop learner autonomy

\begin{tabular}{|c|c|c|c|}
\hline Level & Learner action & Content & Process \\
\hline $\begin{array}{c}\text { Level } \\
1\end{array}$ & Awareness & $\begin{array}{l}\text { Learners are made aware of the pedagogical goals and content of } \\
\text { materials they are using }\end{array}$ & $\begin{array}{l}\text { Learners identify strategy implications of } \\
\text { pedagogical tasks and identify their own } \\
\text { preferred styles/strategies }\end{array}$ \\
\hline $\begin{array}{c}\text { Level } \\
2\end{array}$ & Involvement & $\begin{array}{l}\text { Learners are involved in selecting their own goals from a range of } \\
\text { alternatives on offer }\end{array}$ & $\begin{array}{l}\text { Learners make choices among a range of } \\
\text { options }\end{array}$ \\
\hline $\begin{array}{c}\text { Level } \\
3\end{array}$ & Intervention & $\begin{array}{l}\text { Learners are involved in modifying and adapting the goals and } \\
\text { content of the learning program }\end{array}$ & Learners are modify and adapt tasks \\
\hline $\begin{array}{c}\text { Level } \\
4\end{array}$ & Creation & Learners create their own goals and objectives & Learners create their own learning tasks \\
\hline $\begin{array}{c}\text { Level } \\
5\end{array}$ & Transcendence & $\begin{array}{l}\text { Learners go beyond the classroom and make links between the } \\
\text { content of classroom learning and the world beyond the } \\
\text { classroom and are functioning as a fully autonomous learners }\end{array}$ & Learners become teachers and researchers \\
\hline
\end{tabular}

Holec (1981) presented autonomous learning as an addition to the teacher-led classroom, necessary and separable. He believed that while a teacher-instructed course was plausible, adding autonomous learning to the syllabus would be an advantageous addition. This idea was challenged many years later by Little and Thorne (2017), where they stated that "All successful learning draws on the learners' capacity for autonomous behavior" (p. 44). They added, "learners have experience of autonomy in their lives outside the classroom, and it is the teacher's job to harness the pre-existing capacity for autonomous behavior to the business of language learning" (p. 44). Little and Thorne (2017) added that the development of the target language is inseparable from the development and proficiency in learning autonomously. Little and Thorne (2017) believe that autonomous learning is "a collective as well as an individual capacity, and its development is stimulated by the social-interactive processes on which effective cooperation between teachers and their learners depend" (p. 44). 
Self-study in language learning depends on the learner's choice of activities and strategies, yet it should be supervised by the teacher. Jones (1998) defines EFL self-study as self-guided study designed by a syllabus designed by a school or a purchased package that includes books, CDs, and videos that assists language learning. Most bookstores sell packages and books that promise that the learner would learn a language in a certain time frame. In a study conducted by Algharabali and Taqi (2018), it was found that Kuwaiti female students of English, who identify importance of having a good command of English language learning program by the use of the media, Internet and books. These students were successfully self-taught, had high proficiency in English and developed an American-like accent. This shows that motivation is the core of self-study, along with time management and self-assessment.

Oscarsson (1989) provides several reasons to justify the usefulness of self-assessment in autonomous learning in language learning. One reason he provided was that self-assessment encourages learning; it also provided learners with awareness of their level of knowledge and level of ability. Oscarsson (1989) added that periodic self-assessment promotes motivation and higher levels of goal-orientation, learners broaden their scope of experience, get involved in a teacher-like experience, and learners will attain what they learned post-course.

It is worth noting at this point that studies on self-study have shown that gender is not a significant variable when it comes to self-study strategies (Caliskan \& Seljuk, 2010). Nonetheless, Mahmoud-Mahfouz and Hassan-Ma'Ajini (2013) and Mok et al. (2005) found that female students have a higher degree of strategy awareness. Hence, this study would eliminate gender as a variable.

Following the information provided in the literature and the aim of the study which evolves around examining the possibility of promoting self-learning in EFL contexts higher education, and to what extent is the application of self-study possible, the current study would attempt to answer the following questions:

1) To what degree do EFL students prefer self-study?

2) What do EFL student perceive as necessary skills required for self-study?

3) What resources would EFL students utilize during their self-study?

4) What do EFL students believe are the values acquired from self-study?

5) To what extent do students believe that self-study will affect their language learning?

\section{Methodology}

The current study has been implemented in the College of Basic Education in Fall and Spring of 2018/2019. The College of Basic Educations (CBE) is a four-year college that trains the students to become primary school teachers in different sciences. The participants of this study are 324 female students studying English. Most students studying English have had 12 years of official education in English as English is introduced in the first year of primary school in public schools in. However, due to the lack of time, teachers' experience, and students' interest, many students do not have a good command of the language and need to study English while studying different courses of linguistics, literature and education at the English Department.

The students are first, second, third- and fourth-year students at CBE, whose ages range from 17-30. All the students who participated in this study were graduates of public schools. Private school graduates were eliminated in order to reduce variation caused by their language proficiency. The students were given a 54 statements questionnaire to answer on a five-point Likert scale adapted from Ikonen (2013). The questionnaire was applied and distributed electronically with the use of an on-line poll manager, and via several social platforms, and a note at the beginning was written asking students only to answer the questionnaire once. The questionnaire was run on Alpha-Cronbach for reliability and internal consistence testing via SPSS on 15 participants' answers, the results gaining 0.804 which reflects high reliability.

The statements start with 5 independent variables of age, GPA, availability of the internet, smart phone use, and the use of computers. These statements were followed by 16 statements addressing learning styles that would assist in identifying the students' learning habits. The viewpoint of the learners on the importance of learning language and their motivation to learn was followed with 10 statements. 11 statements addressed the use of material and the Internet while learning. These statements would help identify the students' ability to use proper materiel to study. Finally, 12 statements addressed the independence of learning; these statements are needed to pinpoint the students' beliefs in the importance of independent language learning.

In addition to the questionnaire, the researcher conducted 12 group interviews of 6 students in each group. The interviews were conducted in a meeting room in the English Department. The students were asked about issues connected to self-study. These interviews supported the finding of the questionnaire by eliciting detail answers to 
questions related to their ability and preference to self-study.

The data obtained from the questionnaire was analyzed quantitatively through SPSS 16.0 for frequency, significance of independent variables, mean and standard deviation. On the other hand, the interviews were analyzed qualitatively with the use of sociolinguistic manual analysis.

\section{Results}

The results in this study are two folded. At first, the results were obtained from the 54 statements enlisted in a questionnaire. The questionnaire was analyzed in three main groups; namely, the use of technology, learning methods, and students' views on independent learning. The answers were analyzed individually and in coordination with the two main independent factors of age and GPA.

The second part of the data was qualitative. It was obtained from 12 interview groups consisting 6 students each from several English classes which enabled obtaining clearer insight in the autonomous learning perspective.

\subsection{Questionnaire}

The first three questions in the questionnaire were placed to assure that the students have access to computers, smart phones and the internet. It appeared that $41 \%$ of the students do not have a personal computer; however, all of the students have a smart phone and access to the internet. Hence, it was appropriate to ask questions about learning through the use of smart devises and the internet. Enable to understand the learning styles of the students, which reflects most on the idea of independent learning, the students were asked whether they believe they manage their time well while studying. While $77.6 \%$ of the students stated that they can mostly manage their time well, and $16 \%$ were always able to manage study time well, $5 \%$ think they did not manage their time well. In a one-way ANOVA by GPA by making good use of time, significance was found at $\mathrm{f}=0.04$ (where significance is calculated at $\mathrm{f}=0.05$ ). The reason for this significance seems to be that the students with the lowest GPA did not believe they could manage their study time well.

The majority of students also expressed their belief in their ability to study on their own, and find resources when needed. A one-way ANOVA by GPA on the ability to find resources showed high significance at $\mathrm{f} \leq 0.01$, as the lower GPA students were the least able to find suitable resources. However, $55.6 \%$ of the participants (180 participants) stated that they always learned from their mistakes, and $45.6 \%$ always liked problem-solving exercises; yet, $42 \%$ stated that they were sometimes unable to solve problems they faced while studying.

Do students feel they are able to evaluate their own work? Most of the students feel they always do (112 students), while 24 students did not. Moreover, 244 participants stated they could evaluate the degree of language improvement and would know how to change their method of studying when needed. Most students participating in this study set their own plans and methods for studying and avoid imitating other students. Surprisingly, the majority of students have set their own plan to learn a language and believe they are able to improve their language on their own, without teacher guidance. Figures 1 and 2 below reflect the students' point of view in terms of planning and learning a language autonomously.

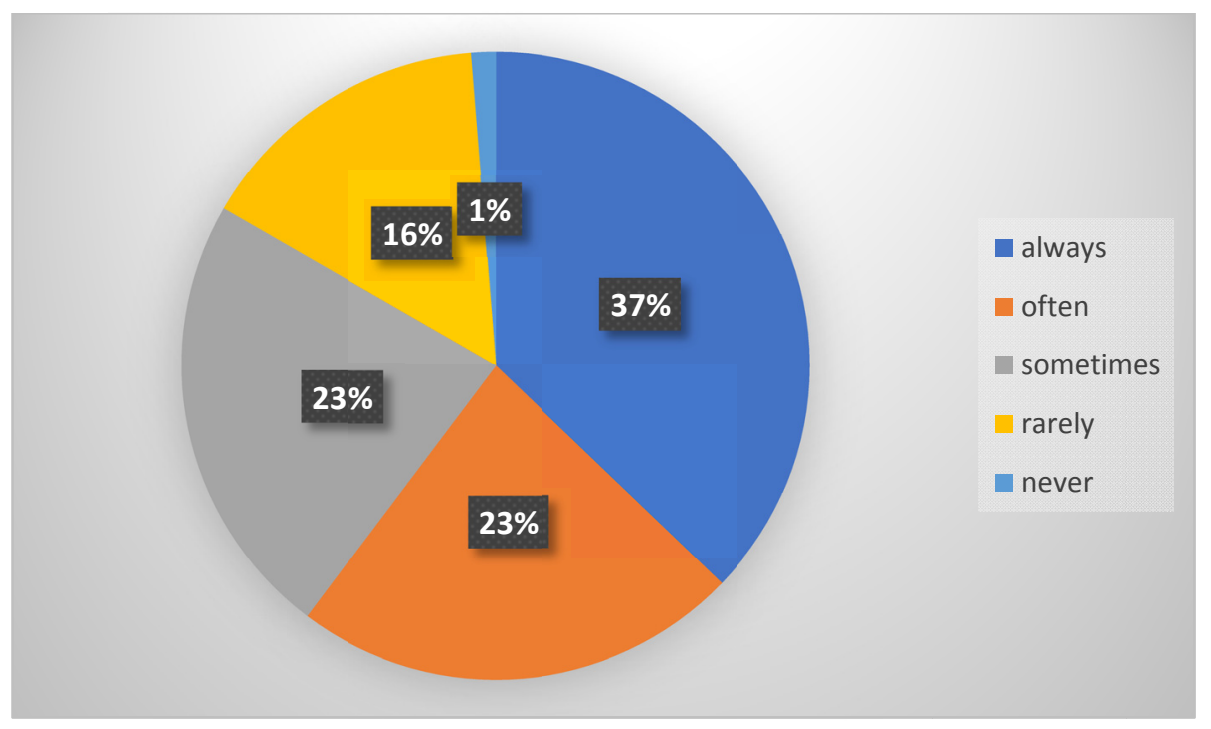

Figure 1. Answers to the statement "I can design a clear plan to improve my language" 


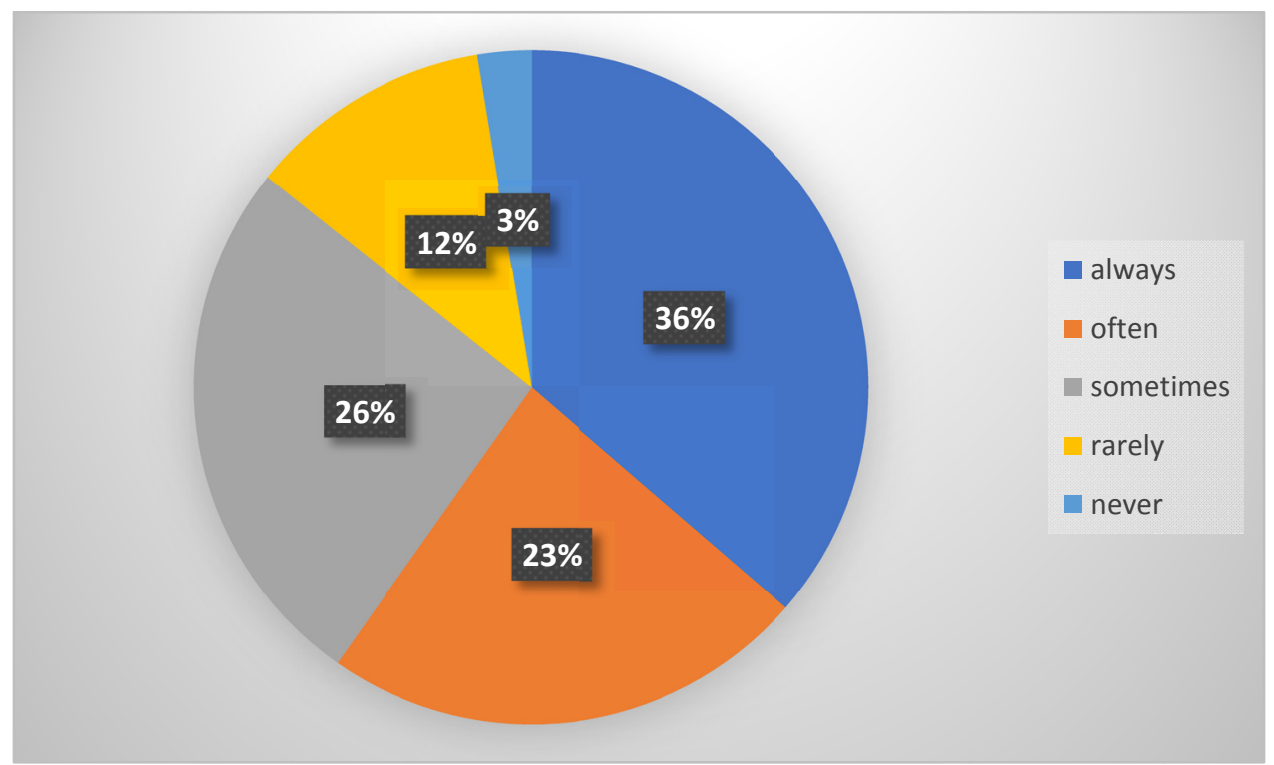

Figure 2. Answers to the statement "I can improve my linguistic abilities without a teacher"

Again, when the students were asked about their point of view on learning, 212 students believed they always found learning a fascinating time in life to search for new ideas; and they also believe that teachers are the best resources for information. The majority of students have also noted that they learn better in class, yet attending class is not sufficient to learn and could not substitute self-study. In a one-way ANOVA by age by the ability to find suitable resources, significance was found at $\mathrm{f} \leq 0.01$, as the oldest group significantly learns better in class. $67.9 \%$ of the students found that cooperative learning insures better learning. That being said, $63 \%$ of the students felt that learning is the teachers' responsibility. While most students do not believe they can find answers to all their questions without the teacher's help, $13.6 \%$ totally disagree. The majority of students also believe that students could not always evaluate their improvement and the best way to gather information (100 and 104 consecutively). When testing this statement in a one-way ANOVA by GPA, high significance was found ( $\mathrm{f} \leq 0.01)$. the reason was found to be that the students with the highest GPA felt that they could not evaluate their level of learning. Figure 3 reflects the statement "attending Classes instead of self-study" by GPA.

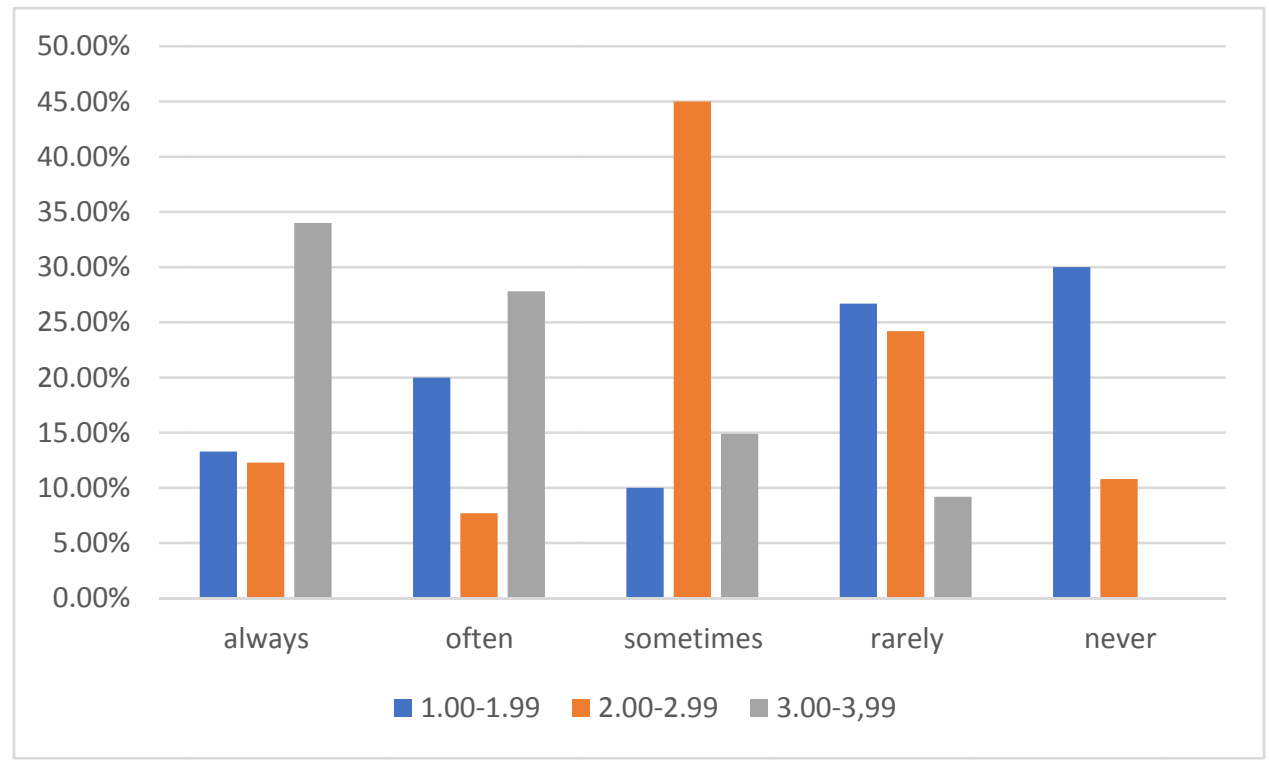

Figure 3. Answers to the statement "attending classes instead of self-study" by GPA 
The ability to use computers, smart phones and surfing the net is one of the main components of learning. It appears from the data that most students are extremely confident while using the computer (160 students), and though 108 students feel completely at ease while using the computer, 84 students sometimes feel irritated. The data reflected a huge variation in answering "I don't use the computer to learn" even though 96 students always do. Figure 4 reflects the fluctuating responses to this statement.

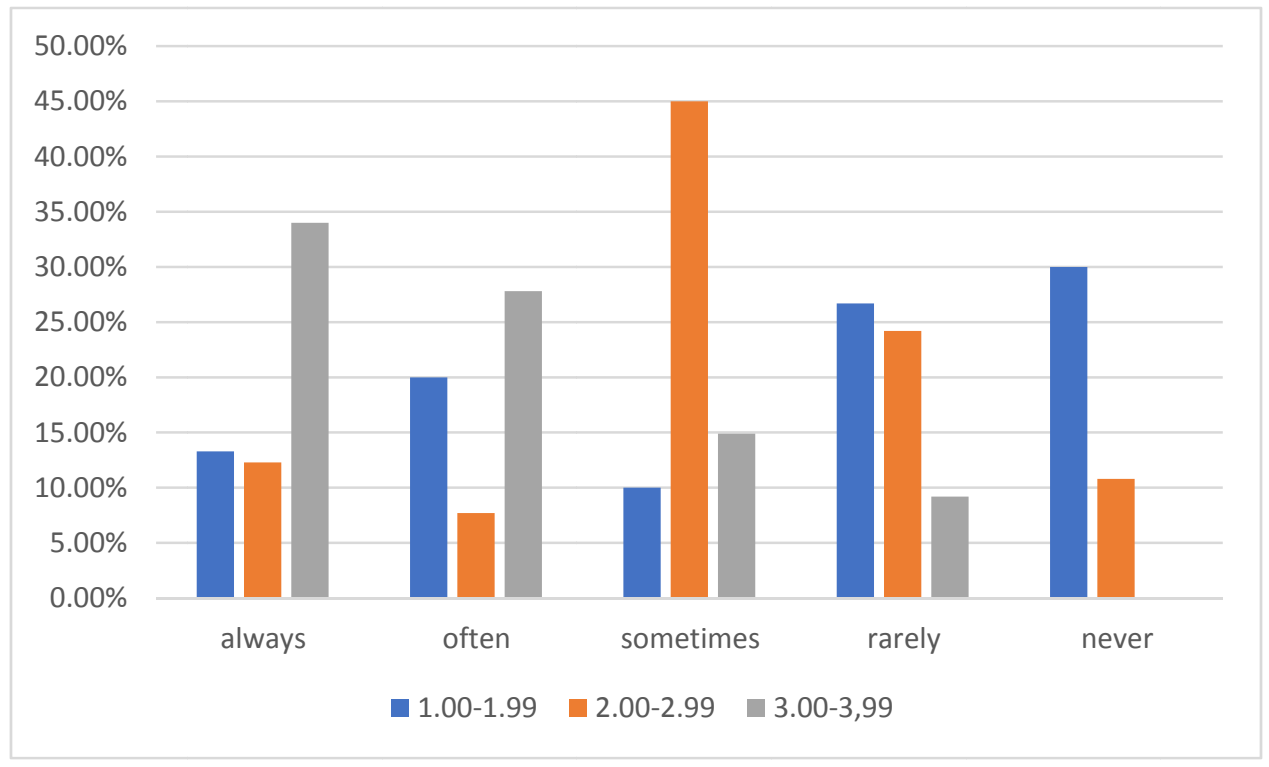

Figure 4. Answers to the statement "I don't use the computer to learn"

Most students participating in this study stated that they found using the computer easy and very helpful in language learning. The data reflects the students' confidence in finding suitable programs that aid language learning. When investigating this point further by a one-way ANOVA by age, significance was found at $\mathrm{f}=0.01$. Apparently, this significance is due to the fact that the eldest age group mostly stated that they fail to find information by surfing the net. However, is surfing the net considered time consuming? Figure 5 reflects the variation in responses received for this statement.

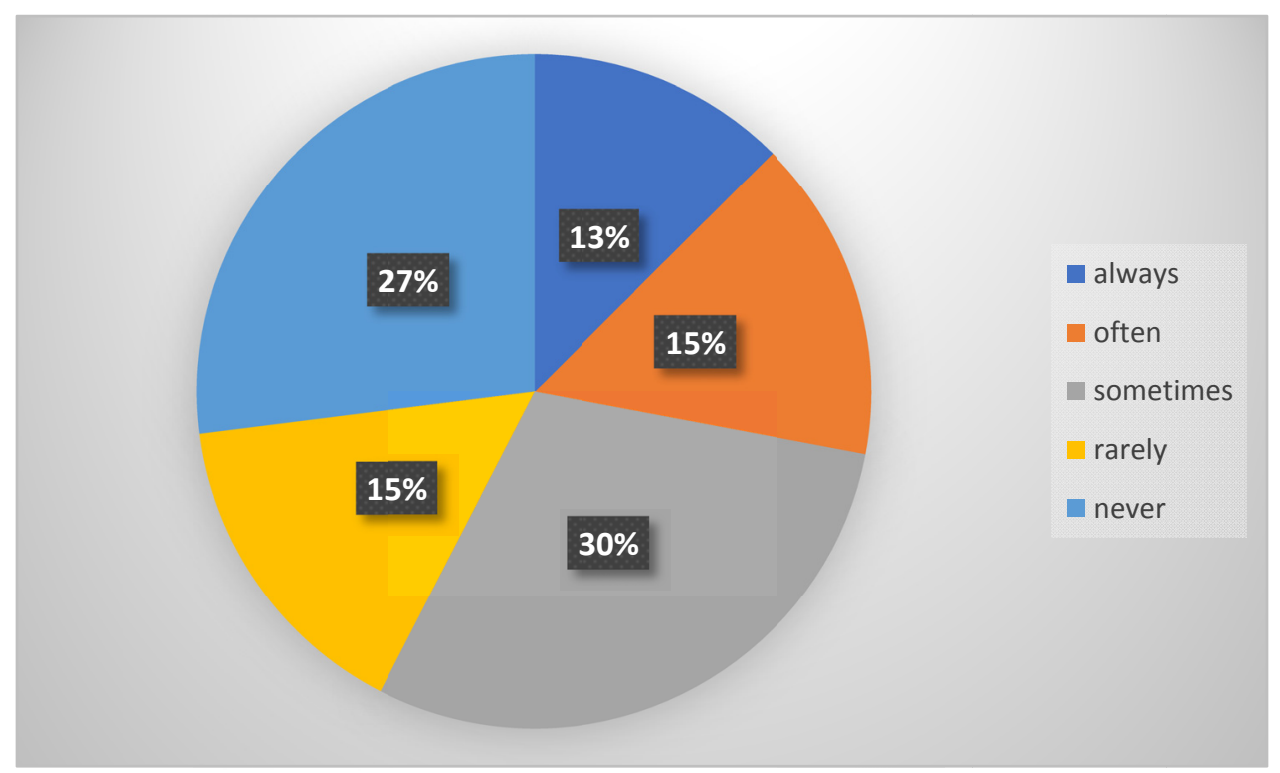

Figure 5. Answers to the statement "surfing the net considered time consuming" 
Independence is a main issue in autonomous learning; hence, 12 statements addressed this issue in the questionnaire. The data showed that most students feel that they could learn English without the help of a teacher $(55.5 \%)$, and only $8.6 \%$ think it is not possible. In fact, 128 of the participants believe that the internet is an adequate substitute for teachers. Nonetheless, 48 participants stated that the internet could never replace teachers. 160 participants (49.3\%) stated that they always use smartphone applications for language learning. While the majority of students reflected high confidence in learning and finding resources on their own, they also insisted on the importance of lectures, noting that lectures should not replace lectures, not even partially. Figure 6 displays students' answers to the statements addressing the importance of lectures and attendance. In a one-way ANOVA by GPA, it was found that students with the lowest GPA reflected less confidence in learning on their own $(\mathrm{f} \leq 0.01)$.

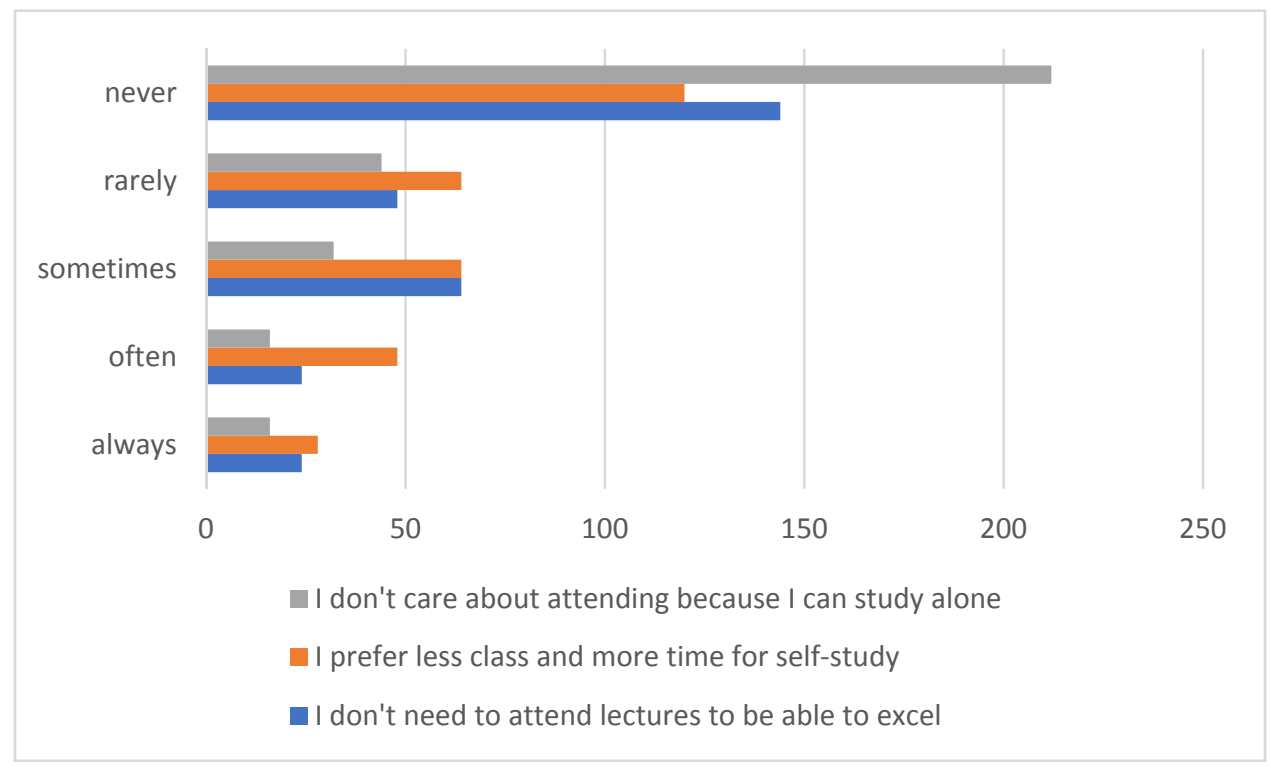

Figure 6. Answers to the statements addressing the importance of lectures and attendance

\subsection{Interviews}

To initiate group interviews, the students were chosen from three English courses; namely, Phonetics and Phonology, Writing, and conversation. The phonetics students were third- and fourth-year students, the writing students were second year students, and the conversation students were first year students. They were all given a situation to imagine where a specific task is given to the students, this task involves a topic they have not been taught previously, each in their courses discipline. The students would, then, be tested for their knowledge on the topic they have been given. The students were asked three main questions:

1) Would they be able to complete the task successfully without the help of their teacher?

2) Could they "confidently" sit for a test?

3) Would they like to have such tasks as part of the class assignments?

The students in the group interview have various GPA levels ranging from 1.86-3.60. Once they were told to imagine the situation, the majority expressed enthusiasm. The students with high GPA believed they could definitely finish the task with ease. The students commented "we can search for answers on the net", one student added "there are useful videos on YouTube that teach us how to do stuff, I always use YouTube". The students with lower GPA and the conversation students reflected less enthusiasm and confidence, but nonetheless, expressed their will to try that experience to be able to decide whether they would like it and could pass it successfully. "How could I know if I can or can't if I don't try first?" asked on student.

While the Phonetics and Phonology and writing students mostly believed they can sit confidently for the exam, the conversation students did not. They mostly felt they needed the teachers' comments on the task and tips to improve their presentation skills. One student commented, "I might know the information, but presenting it needs my teacher's help." Another student asked, "presenting is a practical skill, doesn't a practical skill need in-class practice?" the writing class students believed that one task could be completed independently, hence making 
testing the topics provided in these independent tasks easy, but the course should not be completely independent.

All the participants wanted to try one task to gain the new experience, they provided several reasons

1) To enhance their confidence in their ability to learn independently.

2) To be challenged.

3) To work on their own pace.

4) To choose the studying resources and methods that suits their needs.

5) To explore options and discover better ways of studying.

The students were then asked what approach they would use to complete the task? Most students preferred to surf the net, some students suggested the use of smartphone applications that would help in their area of study, "there are so many applications; it takes time just to choose which one is the best... but many are good really." A few students suggested the use of YouTube and working with friends. Figure 7 below reflects the resources of self-study the students would use in their autonomous learning.

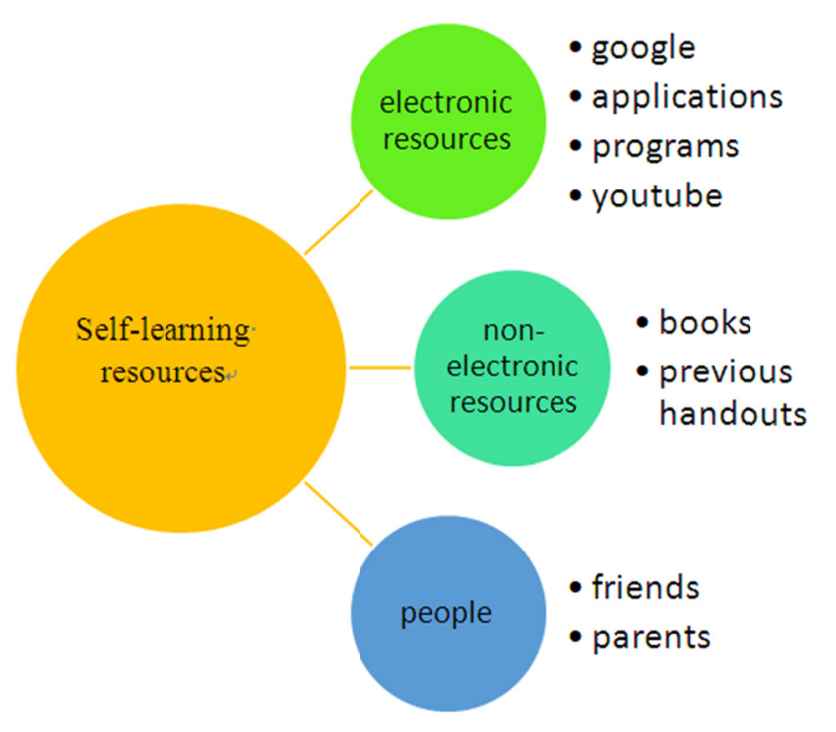

Figure 7. Autonomous learning resources

\section{Discussion}

The current study investigated the students' perception of self-study as part of their curriculum, their knowledge of the skill required to conduct the process, the values that would be gained during their autonomous learning, and the effect of self-study on their language abilities. The data displayed that the majority of the participants believed they could learn autonomously, choosing their preferred method of learning. This coincides with Dickinson's (1993) findings that stated that the students, presented with the suitable self-study environment, would be able to study independently, working in their own pace.

Furthermore, many students in this study expressed their willingness to study independently being motivated by the feeling of independence, and being armed with their knowledge of the use of the internet as the main source of information. Motivation, as stated by Jovaiša (2007) is part of the students' independence, and is definitely the most important factor in building a successful self-study project. However, motivation alone was not considered the sole skill required. Dickinson (1993) found that the ability of students to work on their own pace, their ability to choose what suits their learning abilities, and the ability to participate actively in the learning process are essential autonomous learning traits. In this study, most students felt they have these required skills to learn independently. Yet, freshmen and students with low GPA were less confident and hence less willing to study on their own. This poses the need for teachers' guidance and the importance of the teachers' role in autonomous learning as Ebata (2010) found that developing students' autonomy is an important factor not to be ignored. A teacher's role in self-study is as important as it is in in-class teaching. As reflected by the data, the students believed that, even while 
studying autonomously, their teacher's guidance is essential and could not be minimized. In fact, the majority of students who participated in this study did not prefer to have less in-class hours to self-study, and would prefer to have their teacher's guidance and feedback constantly. Čiburienè and Guščinskiené (2012) states that the teacher must prepare to guide the students throughout the process to ensure that self-study would attain the best possible results.

In the interviews, many students proposed that only a partial amount of the course work would depend on autonomous learning, which in turn would provide them with the opportunity to acquire new skills, but does not add tension to this experience. Daukilas (2010) agreed with this statement emphasizing the teacher's role to adjust the course material to make self-study an authentic experience that could provide the students with the right amount of challenge and tolerance but does not stress them out.

When the students were asked about their preferred method of self-learning, the majority expressed their belief that the internet is the best source of information, along with smartphone applications and consulting with their peers. This idea was emphasized by Daukilas (2010) who noted the fact that self-study does not mean cutting the students off from the world. Instead, interaction is a main skill to learn and enhance during the process of autonomous learning. Self-study will, in turn, teach students to cooperate and investigate options which would make them better teachers, avoiding memorization from textbooks. It appears from the data and interviews that while not all participating students believed they had the required skills to learn autonomously, they unanimously were willing to try this experience believing it would enhance their ability to learn independently, challenging them positively and providing them with the opportunity to work in their own pace choosing the material that suits them best while exploring their educational options. These findings go hand in hand with the literature previously which emphasizes the need to add self-study projects in the language teaching curriculum.

Moreover, as many students in this study reflected their knowledge of the resources available for language learning, the participants all stated that they constantly use technology to improve their English language skills. It appears that for language learners, self-study is not a new concept. This has also been noted by Algharabali and Taqi (2018) who found that students, who were more fluent in English, were self-taught. Hence, self-study for language learning would evidently help improve the language especially with the technology available nowadays, such as surfing the net, downloading and using smartphone applications and watching videos on YouTube.

Having quantitative and qualitative data helped gaining better insight on the issue of EFL autonomous learning. The questionnaire provided an overall view of the student's perspectives, while the interview reflected more detail of the methods and limitations students' find in self-study.

Having only female students was perceived as a limitation, another issue that might hinder clear results is the implementation of the study in one college, one department, thus results might be emphasized by cultural or environmental issues specific to the college. It would be recommended for future study to involve male students and to cover more higher education institutes. In addition, testing the results found in this study by applying them in a task based self-study in some EFL classes will help reassure.

\section{Conclusion}

The following study was conducted in the English Department at the College of Basic Education. The 324 female English-teachers-to-be answered a 54 statements questionnaire that inquired about the students' ability to find learning resources, learn independently, and manage the time and pace of study. In addition to the questionnaire, group interviews were conducted with 72 students to obtain clearer insight on the issues addressed.

The researcher found that although freshmen and students with low GPA were reluctant to completely depend on themselves to learn, all the students were willing to try autonomous learning as part of a course's requirement. Teachers' guidance was found essential however, and most teachers believed that the role of the teacher was indispensable. Learning a language through self-study was not rejected by the participants. In fact, many believed that they had the required skills and tools to engage in this experience. Hence, it would be highly recommended to embed autonomous learning in the syllabus in a well measured technique that would encourage students to depend on themselves, providing them with guidance and instructions to gain various skills such as time management, critical thinking and decision making, which would help them for many years, even during their career as teachers.

This study has found that language learners would gain significantly from self-study especially that all the students in the study stated they had access to the internet, a resource found essential for language learning. In addition, the confidence the students would obtain from such an experience seems to be invaluable. However, language teachers should be fully prepared before engaging their students in autonomous learning. They should have the required knowledge of the topics that are proper for self-learning, the guidance that is suitable for their students that assure 
independence, and the ability to make this experience an interactive one. With the teachers' knowledge and the students' enthusiasm and skills, self-study would surely be a positive experience for higher education system.

\section{References}

Algharabali, N., \& Taqi, H. (2018) Performing Speaking "Ungrammatical" American English: A Kuwaiti Linguistic Phenomenon. Open Journal of Modern Linguistics, 8, 242-261. https://doi.org/10.4236/ojml.2018.86021

Baird, J. R. (1988). Quality: What should make education "Higher". Higher Education Research and Development, 7(2), 141-152. https://doi.org/10.1080/0729436880070205

Benson, P. (2004). Autonomy and information technology in the educational discourse of the information age. In C. Davison (Ed.), Information technology and innovation in language education (pp. 173-192). Hong Kong: Hong Kong University Press.

Benson, P., \& Voller, P. (1997). Introduction. In P. Benson, \& P. Voller (Eds.), Autonomy and independence in language learning (pp. 4-7). London: Longman. https://doi.org/10.1017/s0272263198273062

Çalişkan, S., \& Selçuk, G. S. (2010). Pre-service teachers' use of self-regulation strategies in physics problem solving: Effects of gender and academic achievement. International Journal of Physical Sciences, 5(12), 1926-1938.

Čiburienè, J., \& Guščinskienė, J. (2012). Mokymo(si) metodų ir stiliu dermė aukštojoje mokykloje. Studijos šiuolaikinèje visoumenejje. Mokslo darbai, 3(1), 38-44.

Daukilas, S. (2010). Inovatoriškų dėstytojų edukacinių technologijų bruožai. Management Theory and Studies for Rural Business and Infrastructure Development, 5(24), 45-54.

Dickinson, L. (1993). Aspects of autonomous learning: An interview with Leslie Dickinson. ELT Journal, 17, 330-335. https://doi.org/10.1093/elt/47.4.330

Ebata, M. (2010). Awakening opportunity: Three elements to foster learners' autonomy. Digital Hollywood University.

Greveson, G. C., \& Spencer, J. A. (2005). Self-directed learning- the importance of concepts and contexts. Med. Educ., 39, 348-349. https://doi.org/10.1111/j.1365-2929.2005.02115.x

Holec, H. (1981). Autonomy and Foreign Language Learning. Oxford: Pergamon, Strasbourg: Council of Europe.

Ikonen, A. (2013). Promotion of Learner Autonomy in the EFL Classroom: The student's view (Masters thesis, Department of Languages, University of Jyväskylä).

Jatkauskienè, B., \& Le Boterf, G. (2012). Universiteto dèstytojų profesionalizacijos eskizas (A Schetch of the University Lecturers' Professionalization). Andragogika, 1(3), 48-66.

Johnson, D. W., \& Johnson, R. (1999). Learning together and alone: Cooperative, competitive, and individualistic learning. Boston: Allyn \& Bacon.

Jones, F. (1998). Self-instruction and success: A learner-profile study. Applied Linguistics, 19(3), 378-406. https://doi.org/10.1093/applin/19.3.378

Jovaiša, L. (2007). Enciklopedinis edukologijos žodynas. Vilnius: Gimtasis žodis.

Knowles, M. S. (1975). Self-Directed Learning: A guide for learners and teachers. New York: Associated Press.

Levett-Jones, T. L. (2005). Self-directed learning: Implications and limitations for undergraduate nursing education. Nurse Education Today, 25, 363-368. https://doi.org/10.1016/j.nedt.2005.03.003

Little, D., \& Thorne, S. L. (2017). From Learner Autonomy to Rewilding: A Discussion. In M. Cappellini, T. Lewis, \& A. R. Mompean (Eds.), Learner Autonomy and Web 2.0 (pp. 12-35). Sheffield, UK: Equinox.

Long, H. B. (2006). Skills for Self-directed learning.

Mohamoud-Mahfouz, A. I., \& Hassan-Ma'Ajini, O. B. (2013). Self-learning strategies and their relationship with the development of motivation and self-esteem among a sample of students at king Abdullaziz University (descriptive and comparative study between ordinary and talented students). Life Science Journal, 10(4), 1323-1332.

Mok, M. M. C., Ma, H. S., Yuk, F., Liu, F., \& So, E. Y. P. (2005). Multilevel analysis of primary students' perception and deployment of self-learning strategies. Educational Psychology, 25(1), 129-148. 
https://doi.org/10.1080/0144341042000294930

Moore, M. G. (1973). Toward a theory of independent learning and teaching. Journal of Higher Education, 44(9). 661-679. https://doi.org/10.2307/1980599

Nunan, D. (2000). Autonomy in language learning. Plenary presentation given at the ASOCOPI 2000 conference, Cartengena, Columbia.

Oliveira, A. L., \& Simoes, A. (2006). Impact of sociodemographic and psychological variables on the self-directedness of higher education students. International Journal of Self-Directed Learning, 3(1), 1-13.

Oscarson, M. (1989). Self-assessment of language proficiency: Rationale and applications. https://doi.org/10.1177/026553228900600103

Palmberg, R. (1985). How much English vocabulary do Swedish-speaking primary-school pupils know before starting to learn English at school? In H. Ringbom (Ed.), Foreign language learning and bilingualism (pp. 89-97). Åbo: Publications of the Research Institute of the Åbo Akademi Foundation, 105. https://doi.org/10.1017/s0272263100006999

Pukelis, K., \& Savickienè, I. (2011). The Challenge of Establishing a Common Set of Terms for Discourse, Inquiry, and Research in Educational Science: An Analytically Oriented Philosophy of Educology. International Journal of Educology, 17(1).

Rajeckas, V. (1999). Mokymo organizavimas. Kaunas: Šviesa.

Rupšienè, L., \& Bartusevičienè, I. (2011). Analysis of the concept of effectiveness of studies. Andragogika Mokslo darbai, 1, 59-71.

Rupšienė, L., \&Mažionienė, A. (2011). Savarankiškas darbas aukštojoje mokykloje socialinio pedagogo vadybinių kompetencijų ugdymo požiūriu: studentų nuomonè. Tiltai, 3, 151-158. https://doi.org/10.15181/tbb.v66i1.783

Siminică, M., \& Traistaru, A. (2013). Self-directed learning in economic education. International Journal of Education and Research, 1(12).

Vilkonis, R., \& Barabanova, I. (2010). Vidurinės mokyklos mokiniu savarankiško mokymosi patirtis nuotolinio ir elektroninio mokymo(si) poreikio analizès kontekste. Mokytoju ugdymas, 14(1), 121-136.

Whartorn, G. (2000) Language Learning Strategy Use of Bilingual Foreign Language Learners in Singapore. Language Learning, 50, 203-243. https://doi.org/10.1111/0023-8333.00117

White, C. (2007). Autonomy, independence and control: Mapping the future of distance language learning. Learner autonomy, 10, 56-71.

\section{Copyrights}

Copyright for this article is retained by the author(s), with first publication rights granted to the journal.

This is an open-access article distributed under the terms and conditions of the Creative Commons Attribution license (http://creativecommons.org/licenses/by/4.0/). 